Case Reports in
Gastroenterology
Case Rep Gastroenterol 2020;14:491-496

DOI: $10.1159 / 000508847$

Published online: October 15, 2020

(c) 2020 The Author(s)

Published by S. Karger AG, Base www.karger.com/crg

This article is licensed under the Creative Commons Attribution-NonCommercial 4.0 International License (CC BY-NC) (http://www.karger.com/Services/OpenAccessLicense). Usage and distribution for commercial purposes requires written permission.

\title{
Spontaneous Regression of Advanced Hepatocellular Carcinoma
}

\author{
Dhiraj J. Sonbare ${ }^{a, b}$ Rupal Bandi ${ }^{a, c}$ Vivek Sharma ${ }^{a}$ \\ Thomas Cacciarelli ${ }^{a, b}$ Obaid S. Shaikh ${ }^{a, d}$ \\ aveterans Affairs Pittsburgh Healthcare System, Pittsburgh, PA, USA; 'bivision of \\ Transplant Surgery, University of Pittsburgh School of Medicine, Pittsburgh, PA, USA; \\ 'Department of Radiology, University of Pittsburgh School of Medicine, \\ Pittsburgh, PA, USA; ${ }^{d}$ Division of Gastroenterology, Hepatology and Nutrition, University \\ of Pittsburgh School of Medicine, Pittsburgh, PA, USA
}

\section{Keywords}

Cirrhosis - Tumor thrombus · Carcinogenesis

\begin{abstract}
Hepatocellular carcinoma (HCC) is a leading cause of cancer-related mortality. The tumor carries poor prognosis with curative therapeutic options limited to surgical resection, tumor ablation, and liver transplantation. Rarely, there is spontaneous regression of the tumor. We describe the case of a 74-year-old male with cirrhosis from non-alcoholic steatohepatitis who developed advanced HCC that was associated with tumor invasion of the portal vein and marked elevation of serum alfa-fetoprotein level. The patient received no cancer-specific therapy. However, 1 year after the initial diagnosis, he was noted to have complete regression of the tumor. In this report, we discuss possible mechanisms of spontaneous tumor regression and its therapeutic implications.

(C) 2020 The Author(s)

Published by S. Karger AG, Basel
\end{abstract}

\section{Introduction}

Hepatocellular carcinoma (HCC) ranks 6th in the incidence of malignant disorders and 4th among the leading causes of cancer-related deaths globally [1]. In the US, although the overall cancer incidence rate has decreased, the incidence of hepatic and biliary cancers has 


\section{Case Reports in Gastroenterology}

Case Rep Gastroenterol 2020;14:491-496

DOI: $10.1159 / 000508847$

(c) 2020 The Author(s). Published by S. Karger AG, Basel www.karger.com/crg

Sonbare et al.: Regression of Hepatocellular Carcinoma

increased among both men and women [2]. Between 2000 and 2016, the rate of death from HCC increased from 7.2 to 10.3 per 100,000 [3]. In 2019, an estimated 42,030 new cases of liver and intrahepatic bile duct cancer developed resulting in 31,780 deaths [4]. Early diagnosis of HCC is essential. Curative treatment options are limited to surgical resection, tumor ablation, and liver transplantation $[3,5]$. Overall, the prognosis of HCC remains poor with a 5year survival rate of $18 \%$ [6]. In rare instances, there is spontaneous regression of the tumor. We describe a patient who developed advanced HCC with macrovascular invasion and marked elevation of serum AFP level. He received no HCC-specific treatment but was subsequently noted to have complete tumor regression.

\section{Case Report}

A 74-year-old white male presented with abdominal pain and was incidentally noted to have cirrhotic liver morphology on CT abdominal imaging. He denied any episodes of abdominal distention, confusion, or gastrointestinal bleeding. A review of his records revealed mild elevation of serum ALT level for 15 years and low platelet count for 3 years. His past medical history was remarkable for obesity, type 2 diabetes, dyslipidemia, hypertension, hypothyroidism, and prostatism. He had coronary artery stenoses requiring bypass grafting and also had a cholecystectomy. His medications included aspirin, amlodipine, metoprolol, atorvastatin, insulin, metformin, ferrous sulfate, finasteride, and levothyroxine. He was a nonsmoker and did not consume alcohol. There was no family history of liver disease. On physical examination, he was noted to be obese with a body mass index of 39 . He had no scleral icterus, palmar erythema, or lower extremity edema. His abdomen was soft without any distention and liver and spleen were both impalpable. He was alert and oriented and had no asterixis. Blood tests revealed the following: white cell count $3.8 \times 10^{3} / \mu \mathrm{L}$, hemoglobin $14.4 \mathrm{~g} / \mathrm{dL}$, platelets $67 \times 10^{3} / \mu \mathrm{L}$, INR 1.3 , sodium $137 \mathrm{mEq} / \mathrm{L}$, creatinine $0.66 \mathrm{mg} / \mathrm{dL}$, total bilirubin $3.0 \mathrm{mg} / \mathrm{dL}$ (direct 0.8), ALT $38 \mathrm{U} / \mathrm{L}$, AST $39 \mathrm{U} / \mathrm{L}$, alkaline phosphatase (AP) $78 \mathrm{U} / \mathrm{L}$, and albumin $3.4 \mathrm{~g} / \mathrm{dL}$. Further testing showed: HbA1c 7.3\%, serum ferritin $49 \mathrm{ng} / \mathrm{mL}$, alfa1-antitrypsin $122 \mathrm{mg} / \mathrm{dL}$, and ceruloplasmin $21 \mathrm{mg} / \mathrm{dL}$. He was positive for anti-HAV IgG antibody and negative for HBsAg and for anti-HBs, anti-HBc, and anti-HCV antibodies. An HIV test was also negative. Anti-nuclear and anti-smooth muscle antibodies were positive at low titers while anti-mitochondrial antibody was negative. He was diagnosed to have cirrhosis from NASH that was Child's B (Child-Pugh score 8) in severity with a Model for End-Stage Liver Disease (MELD) score of 14. He had no evidence of complications related to cirrhosis including ascites, encephalopathy, variceal bleeding, or HCC. He was advised to institute weight loss measures and to optimize control of diabetes, and further follow-up was arranged.

His condition remained stable; however, 9 months later he presented with abdominal distention, nausea, and vomiting. Examination revealed an ill-appearing male with moderate ascites and no peripheral edema. He was fully oriented and had no asterixis. Laboratory studies revealed: serum total bilirubin level $6.2 \mathrm{mg} / \mathrm{dL}$ (direct 0.8), ALT $37 \mathrm{U} / \mathrm{L}$, AP $117 \mathrm{U} / \mathrm{L}$, albumin $3.5 \mathrm{~g} / \mathrm{dL}$, sodium $136 \mathrm{mEq} / \mathrm{L}$, creatinine of $0.9 \mathrm{mg} / \mathrm{dL}$, and INR 1.3. However, AFP level was markedly elevated at $27,427 \mathrm{ng} / \mathrm{mL}$. An abdominal ultrasound revealed a nodular liver and a 5-cm hypoechoic lesion in the right hepatic lobe and thrombosed right portal and main portal vein. A contrast-enhanced CT scan showed cirrhosis and a 4-cm hypodense lesion in hepatic segment 8 . There was complete thrombosis of the right portal vein branches contiguous with the lesion, and an expansile thrombus in the right portal and main portal vein indicative of tumor thrombosis. Additionally, multiple intra-abdominal venous collaterals, splenomegaly, 


\section{Case Reports in Gastroenterology}

Case Rep Gastroenterol 2020;14:491-496 DOI: $10.1159 / 000508847$

(c) 2020 The Author(s). Published by S. Karger AG, Basel www.karger.com/crg

Sonbare et al.: Regression of Hepatocellular Carcinoma

and moderate ascites were noted (Fig. 1). An MRI scan with contrast showed similar findings. Ascites cytology was negative for malignant cells. An upper gastrointestinal endoscopy showed large non-bleeding esophageal varices. Metoprolol was discontinued and he was initiated on nadolol as primary prophylaxis for variceal bleeding. A multi-disciplinary liver tumor board determined that the patient had HCC with portal vein invasion and tumor thrombus. He was therefore deemed not to be an appropriate candidate for surgical resection, locoregional therapy, or liver transplantation. In view of decompensated cirrhosis, systemic therapy was not considered and he was placed on best supportive care.

During follow-up, the patient reported periodic confusion that was treated with oral lactulose and rifaximin. Ascites was well managed with low salt diet and diuretics. Eight months later, he had well controlled ascites and encephalopathy, and a serum AFP level that had declined to $10,376 \mathrm{ng} / \mathrm{mL}$. No imaging studies were performed and he was maintained on supportive care. One year after the initial diagnosis of HCC, he presented with abdominal distention. He was alert and oriented, had moderate ascites and no peripheral edema. Laboratory studies were as follows: serum total bilirubin $3.3 \mathrm{mg} / \mathrm{dL}$, ALT $15 \mathrm{U} / \mathrm{L}$, AST $21 \mathrm{U} / \mathrm{L}$, AP $120 \mathrm{U} / \mathrm{L}$, albumin $3.0 \mathrm{~g} / \mathrm{dL}$, INR 1.4, serum creatinine 1.05, and AFP $5.0 \mathrm{ng} / \mathrm{mL}$. A contrast-enhanced abdominal CT showed large ascites, nodular liver, a $2.5-\mathrm{cm}$ ill-defined, non-enhancing right hepatic lobe lesion and resolution of expansile right portal and main portal vein thrombus (Fig. 2). Repeat testing showed persistently normal serum AFP levels. Those findings were indicative of complete spontaneous regression of advanced HCC that had invaded the main portal vein. Two years after the initial diagnosis of HCC, the patient remained in a stable state.

\section{Discussion}

Spontaneous cancer regression has remained an intriguing phenomenon since the publication of the first case series more than a century ago [7, 8]. Partial spontaneous regression of HCC was first reported in 1972 [9] and complete regression in 1982 [10]. It has since been described among patients with tumor metastases $[11,12]$. However, spontaneous regression remains a rare phenomenon. In a meta-analysis of ten phase 3 treatment trials of $\mathrm{HCC}$, the rate of spontaneous objective partial regression of HCC was $0.4 \%$ [13]. Spontaneous regression of HCC with tumor thrombosis is even rarer. In one report, a 2-cm HCC involving the left branch of the portal vein was treated with transarterial chemoembolization (TACE). Four months after TACE, he was noted to have tumor thrombus in the main portal vein and diffuse metastases in the left hepatic lobe. However, 12 months later and without any treatment, there was complete disappearance of tumor and tumor thrombus [14]. In another report, a large HCC with left portal and hepatic vein thrombosis and multiple pulmonary metastases underwent complete spontaneous regression [12]. We described a case of advanced HCC associated with tumor thrombosis of the portal vein and marked elevation of serum AFP level that regressed completely without ablative or systemic therapy.

Spontaneous tumor regression is a partial or complete involution of a malignancy without application of a specific therapy [8]. Several mechanisms have been suggested, principal among them tumor ischemia and immune response [15]. In an individual patient, either or both mechanisms may be in play. Possible causes of tumor ischemia include arterial thrombosis or occlusion, rapid tumor expansion that outpaces neovascularization, and development of arterioportal shunts. Immunologic mechanisms involve immune checkpoints that are pathways required to maintain self-tolerance [16]. Carcinogenesis employs immune checkpoint activation that inhibits anti-tumor immune responses. Spontaneous failure or therapeutic 


\section{Case Reports in Gastroenterology}

\begin{tabular}{l|l}
\hline Case Rep Gastroenterol 2020;14:491-496 \\
\hline DOI: 10.1159/000508847 & $\begin{array}{l}\text { @ 2020 The Author(s). Published by S. Karger AG, Basel } \\
\text { www.karger.com/crg }\end{array}$ \\
\hline
\end{tabular}

Sonbare et al.: Regression of Hepatocellular Carcinoma

blockade of such mechanisms can result in tumor suppression [16]. In addition to multi-kinase inhibitors (sorafenib, lenvatinib, regorafenib, cabozantinib) and human vascular growth factor receptor antagonist (ramucirumab), US Food and Drug Administration has approved immune checkpoint inhibitors (nivolumab, pembrolizumab, ipilimumab) alone or in combination with other agents as treatment for HCC [17].

The patient described did not receive cancer-specific therapy and was managed with best supportive care. Despite advanced disease, as evidenced by marked elevation in serum AFP level and tumor involvement of the portal vein, there was complete spontaneous regression of HCC. This assessment was based on contrast-enhanced CT imaging and persistent decline in serum AFP level to within normal limits. The underlying mechanisms of tumor regression likely involved vascular phenomena and immunologic pathways as discussed earlier. A better understanding of such mechanisms will help develop more effective therapies for cancer.

\section{Statement of Ethics}

This submission conforms to the internationally accepted standards for research practice and reporting. Approval from the Veterans Affairs Pittsburgh Healthcare System Institutional Review Board was not required as this was a single case report and identifying information was not used. The patient and his wife provided informed consent for this submission and that was placed in the electronic medical records.

\section{Conflict of Interest Statement}

During the last 3 years, Obaid Shaikh, MD, received grant support from: Gilead Sciences, Pfizer, Mallinckrodt pharmaceuticals and Merit Medical Systems. All other authors received no outside financial support. None of the authors have a financial conflict of interest related to this submission.

\section{Funding Sources}

The authors received no outside funding for this work.

\section{Author Contributions}

Dhiraj Sonbare, MD, developed the concept and wrote the first draft. Rupal Bandi, MD, Vivek Sharma, MD, and Thomas Cacciarelli, MD, participated in development of the concept and critically reviewed the manuscript. Obaid Shaikh, MD, developed the concept, reviewed and revised the manuscript and wrote the final draft. All authors approved the final version and are in agreement to be accountable for all aspects of the work. 


\section{Case Reports in Gastroenterology}

\begin{tabular}{l|l}
\hline Case Rep Gastroenterol 2020;14:491-496 \\
\hline DOI: 10.1159/000508847 & $\begin{array}{l}\text { @ 2020 The Author(s). Published by S. Karger AG, Basel } \\
\text { www.karger.com/crg }\end{array}$ \\
\hline
\end{tabular}

Sonbare et al.: Regression of Hepatocellular Carcinoma

\section{References}

1 International Agency for Research on Cancer WHO. Cancer today. 2019.

2 Ward EM, Sherman RL, Henley SJ, Jemal A, Siegel DA, Feuer EJ, et al. Annual Report to the Nation on the Status of Cancer, Featuring Cancer in Men and Women Age 20-49 Years. J Natl Cancer Inst. 2019 Dec;111(12):1279-97.

3 Villanueva A. Hepatocellular Carcinoma. N Engl J Med. 201904 11;380(15):1450-62.

4 Surveillance, Epidemiology, and End Results (SEER) Program. National Cancer Institute; 2019.

5 Granito A, Bolondi L. Non-transplant therapies for patients with hepatocellular carcinoma and Child-PughTurcotte class B cirrhosis. Lancet Oncol. 2017 Feb;18(2):e101-12.

6 Jemal A, Ward EM, Johnson CJ, Cronin KA, Ma J, Ryerson B, et al. Annual report to the Nation on the status of cancer, 1975-2014, featuring survival. J Natl Cancer Inst. 2017 Sep;109(9).

7 Rohdenburg GL. Fluctuations of the growth energy of malignant tumors in man with especial reference to spontaneous regression. J Cancer Res. 1918;(3):193.

8 Cole WH, Everson TC. Spontaneous regression of cancer: preliminary report. Ann Surg. 1956 Sep;144(3):366-83.

9 Johnson FL, Lerner KG, Siegel M, Feagler JR, Majerus PW, Hartmann JR, et al. Association of androgenicanabolic steroid therapy with development of hepatocellular carcinoma. Lancet. 1972 Dec;2(7790):1273-6.

10 Gottfried EB, Steller R, Paronetto F, Lieber CS. Spontaneous regression of hepatocellular carcinoma. Gastroenterology. 1982 Apr;82(4):770-4.

11 Ohba K, Omagari K, Nakamura T, Ikuno N, Saeki S, Matsuo I, et al. Abscopal regression of hepatocellular carcinoma after radiotherapy for bone metastasis. Gut. 1998 Oct;43(4):575-7.

12 Pectasides E, Miksad R, Pyatibrat S, Srivastava A, Bullock A. Spontaneous regression of hepatocellular carcinoma with multiple lung metastases: a case report and review of the literature. Dig Dis Sci. 2016 2016/09/01;61(9):2749-54.

13 Oquiñena S, Guillen-Grima F, Iñarrairaegui M, Zozaya JM, Sangro B. Spontaneous regression of hepatocellular carcinoma: a systematic review. Eur J Gastroenterol Hepatol. 2009 Mar;21(3):254-7.

14 Koya Y, Suzuki T, Tai M, Ichii O, Matsuhashi N, Ejiri Y, et al. Spontaneous Regression of Hepatocellular Carcinoma with Portal Vein Tumor Thrombus. Case Rep Gastroenterol. 2018 Aug;12(2):411-9.

15 Huz JI, Melis M, Sarpel U. Spontaneous regression of hepatocellular carcinoma is most often associated with tumour hypoxia or a systemic inflammatory response. HPB (Oxford). 2012 Aug;14(8):500-5.

16 Wei SC, Duffy CR, Allison JP. Fundamental mechanisms of immune checkpoint blockade therapy. Cancer Discov. 2018 Sep;8(9):1069-86.

17 Hematology/Oncology (Cancer) Approvals \& Safety Notifications. www.fda.gov. Accessed May 8, 2020. 
Case Reports in Gastroenterology
Case Rep Gastroenterol 2020;14:491-496

DOI: $10.1159 / 000508847$

(c) 2020 The Author(s). Published by S. Karger AG, Basel www.karger.com/crg

Sonbare et al.: Regression of Hepatocellular Carcinoma

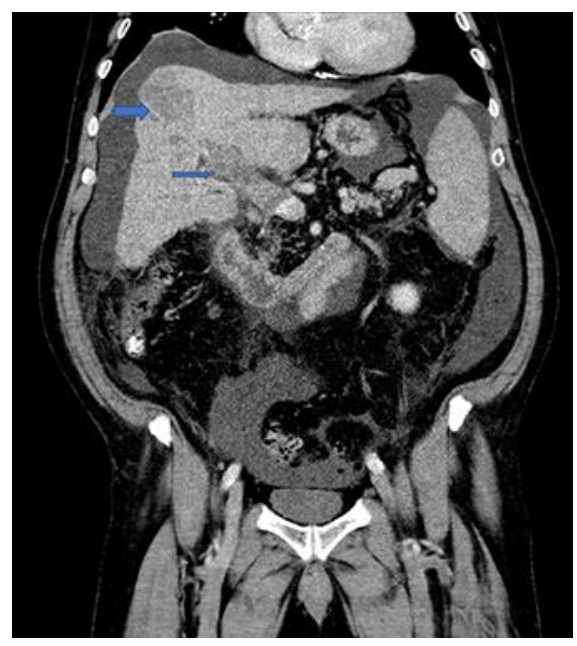

Fig. 1. Contrast-enhanced CT scan shows a hypodense lesion in segment 8 (large arrow) and expansile thrombus in the portal vein (small arrow).

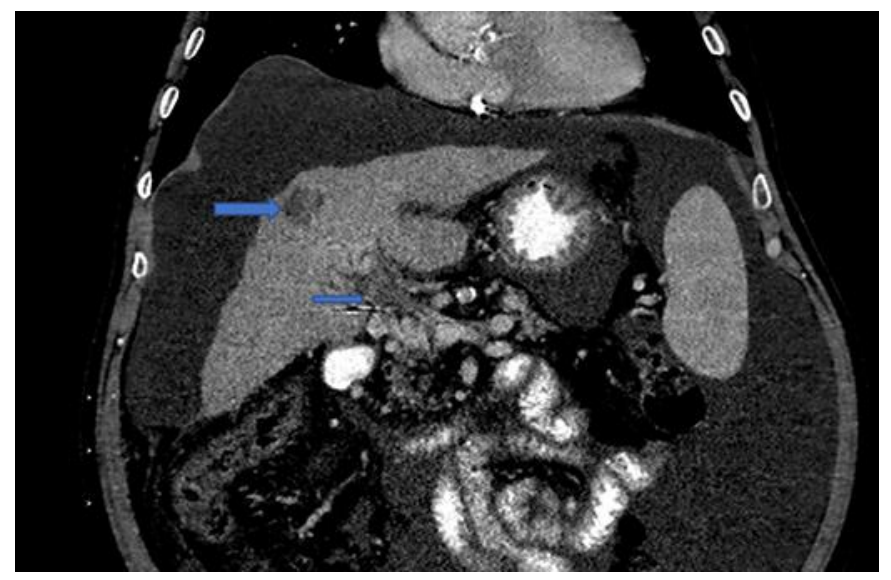

Fig. 2. Contrast-enhanced CT scan shows an ill-defined, non-enhancing lesion (large arrow) in segment 8 and resolution of expansile portal vein thrombus (small arrow). 